\title{
Research progress in physiological and molecular biology mechanism of drought resistance in rice*
}

\author{
Qiang Chen ${ }^{1,2}$, Siyuan Tao ${ }^{1}$ Xiaohua $\mathrm{Bi}^{2}$, Xin $\mathrm{Xu}^{1}$, Lanlan Wang ${ }^{3}$, Xuemei $\mathrm{Li}^{3 \#}$ \\ ${ }^{1}$ Experimental Center, Shenyang Normal University, Shenyang, China \\ ${ }^{2}$ Department of Horticulture, Shenyang Agricultural University, Shenyang, China \\ ${ }^{3}$ College of Chemistry and Life Science, Shenyang Normal University, Shenyang, China \\ Email: ${ }^{*}$ hq2012lunwen@126.com
}

Received 21 February 2013; revised 10 April 2013; accepted 20 April 2013

Copyright (C) 2013 Qiang Chen et al. This is an open access article distributed under the Creative Commons Attribution License, which permits unrestricted use, distribution, and reproduction in any medium, provided the original work is properly cited.

\begin{abstract}
Rice is one of the most important crops, providing staple food for about half population of the world. Drought stress affects plant growth and development seriously. This article reviewed the research progress of the physiological and molecular biology mechanism including osmotic adjustment, scavenging oxidative radicals, endogenous hormones, drought-resistance genes and epigenetic modification, it may be afford interrelated reference for increasing rice drought resistance and breeding drought resistance rice varieties.
\end{abstract}

Keywords: Rice; Drought Resistance; Physiology and Biochemistry; Methylation; Epigenetics

\section{INTRODUCTION}

Rice is one of the most important crops, providing staple food for about half population of the world [1]. Rice production must be increased $60 \%$ so as to meet for the contention by the year 2025 [2]. A growing population, urbanization, industrialization, pollution, and drought have compounded the shortage of water resources [3]. Drought is one of the most important constraints in crop resulting in large yield losses and limiting the average yield increase. In fact, since the 1990s China's average annual drought-affected area was up to 26.67 million hectares decreasing food production by $70-80$ billion $\mathrm{kg}$ [4]. Therefore, the development and production of drought-resistant rice varieties is be of great significance in ensuring food security, shortage of water resources, protecting environment and increasing income. The article reviewed the research progresses of the Physiological

*National Natural Science Foundation of China (30870205); Shenyang Normal University Experimental Center director funds (Sy201104).

${ }^{\#}$ Corresponding author. and molecular biology mechanism, which could supply interrelated reference for increasing rice drought resistance and breeding drought resistance rice varieties.

\section{PHYSIOLOGICAL MECHANISM DROUGHT RESISTANCE IN RICE}

\subsection{Osmoregulation Substance}

Study has shown that cellular holds turgidity through inducing solute accumulation and decrease of osmotic potential [5]. Osmoregulation substance could be classified two categories according to mechanism of action: One is inorganicions adjusting osmotic potential of vacuole, such as $\mathrm{K}^{+}, \mathrm{Na}^{+}$etc., the other is organic matter adjusting osmotic potential of cytoplasm, such as proline, betaine etc. [6]. Cai et al. [7] argued that ability of leaf osmoregulation is greater than the root after subjecting to water stress at different growth stages; In addition, $\mathrm{K}^{+}$ gave the greatest contribution to whether roots or leaves, secondly $\mathrm{Ca}^{2+}$. The sequence ordered based on content is $\mathrm{K}^{+}>\mathrm{Ca}^{2+}>$ soluble sugar $>\mathrm{Mg}^{2+}>$ free amino acid $>$ proline, however, the sequence is proline $>$ free amino acid $>$ soluble sugar $>\mathrm{K}^{+}>\mathrm{Mg}^{2+}>\mathrm{Ca}^{2+}$ according to extent of increase. (Cai et al., 2008). Cabuslay et al. [8] revealed that ability of leaf osmoregulation is also greater than the root after subjecting to water stress. The results of experiment in wheat also showed that $\mathrm{K}^{+}$gave the greatest contribution in drought stress, yet the sequence $\left(\mathrm{K}^{+}>\right.$soluble sugar $>$free amino acid $>\mathrm{Ca}^{2+}>$ $\mathrm{Mg}^{2+}>$ Pro) is different from that in rice [9]. The difference of Osmoregulation in contribution rate could be concerned with plant varieties, growth stages, intensity, environment, and time in stress.

In the last years, studies have showed small organic molecules play an important role such as proline, glycine, betaine, trehalose, mannitol, fructosan, etc. [10,11]. Studies indicated that accumulation of proline and betaine 
could decrease extent of damage [12]. Since 1954 accumulation of free Proline was discovered, the relation of accumulation of free proline and water stress was studied widely [13]. Content of free praline would had a multiplication in crops such as sorghum, sorghum, rice etc. [14-16]. Proline was synthesized through $\operatorname{P5CS}\left(\triangle^{\wedge} 1\right.$ pyrrolin-5-carboxylate synthetase), but it was synthetized by ornithine in normal conditions (Delauney et al. [17] and. Sheela et al. [18] indicated that there was close relationship between free proline and drought resistance because of the strong hydratability to hold on water. Wu et al.'s [19] study showed that the gene for $\mathrm{Na}^{+} / \mathrm{H}^{+}$of reverse transport protein was expressed efficiently in rice and then activated biosynthesis of proline. Moreover, content of $\mathrm{Na}^{+}$and proline in transgenic were above them in contrast. Storey et al. [20] indicated that salinity and water result in accumulation of Glycine-beyaine in barley.

\subsection{The ROS-Eliminating System}

Production and elimination of ROS (reactive oxygen species) was in balance [21,22]. The ROS could pose a hazard to plant cells in adversity. The plant eliminated the ROS by antioxidase system and antioxidant [23-25]. Antioxidase system includes superoxide dismutase (SOD), peroxidase (POD) catalase (CAT) and ascorbate peroxidase (APX-POD). Generally, high and low of antioxidase activity is connected to stress resistance in plant. The stronger stress resistance, the higher antioxidase activity [26,27]. There are diversities of antioxidase activity in different plant. SOD is in centre of antioxidase system and Widespread in the plant body $[28,29]$. In addition, the POD and CAT are also major members of antioxidase system, playing a very important in stress drought. The research showed the protective enzymes of seedlings were increased significantly by pre-treating seeds with water and 10\% - 15\% PEG and that effect of appropriate pre-treating with PEG is super to effect of pre-treating with water [30]. Wu et al. [31] proved that drought stress could result in increasing of significantly. In further, the study showed Antioxidase activities in plant leaf were higher than them in plant root significantly. In the ROS-eliminating system, antioxidant also played a significant role such as ascorbic acid (ASA), glutathione (GSH), carotenoid, etc. These substance quenched reactive oxygen species by several ways directly or indirectly $[32,33]$.

\subsection{Signal Molecule-Hormone}

Plant hormone the generic terms of growth regulation with trace by synthesizing in plant. Although simpleness in chemical structure, it has the complicated physiological effect [34]. The growth and development of every stages was regulated by the hormone [35]. During the reaction process to water stress, the plant hormone perform a key role in the signal transduction. At present, the research on this field is one of the most pop content in life science [36-40]. ABA (abscisic acid) was mostly researched in plant hormone [41]. Most research showed that ABA was the major signal substance, especially for root. In the early 1960s, Wright and Hiron [42] had proved that osmosis stress could induce synthesis of ABA in cellular and synthesis of ABA had great relationship with stress drought. At the same time, ABA could be used for evaluation index in authenticating stress drought. Research showed that ABA could adjust stomatal behavior of plant to enhance stress drought[41]. Root is earlier than leaf in the synthesis of ABA [43]. Chen et al. [44] proved that content of cytokine in the rice organs (overground part) change unconspicuously, yet ABA changed remarkably in content. Studies showed that hormonal balance was effected in water stress. Content of cytokinin and ethylene decreased, yet content of ABA increased significantly $[45,46]$. In addition, Yang et al. [47] argued that antagonism of ABA and ethylene regulated the development of spikelet, furthermore Ratio of ABA and ethylene is a physiological feature coping with water stress.

In recent years, researches about SA (salicylic acid), BR (brassinolide) [48,49], JA (jasmonic acid) [50-54,] were studied in water stress. In addition, some secondary metabolites such as peptide, NO, SL (strigol-actones), etc, play a part like hormone in growth and development [55]. Wu et al. [56] argued that a new regulatory factor, protein (14-3-3), was in signal transduction pathway of brassinolide. In addition, they also reveal a new regulating mechanism for protein OsBZR1. This Would supply a new way and means for plant in stress drought.

\section{RESEARCH ADVANC OF DROUGHT RESISTANCE INMOLECULAR BIOLOGY}

During adapting to the drought stress, the plant has some reactions in molecular level. The reactions were regulated by several genes forming response systems to the drought [57]. Drought genes were divided into two classes according to the way of action [58]. The first is function genes with protecting directly in drought resisting; the second is regulation genes, productions which encold could regulate function genes in signal transduction and gene expression.

\subsection{Function Gene with Drought-Resistance}

Research showed that there were several significant differences between transgenic rice with gene for GST and CAT1 and normal rice in growth, photosynthesis, reduction extent of RWC (relative water content), accumulation of $\mathrm{H}_{2} \mathrm{O}_{2}$ and MDA (malon dialdehyde) and 
so on. These results implied that the GST and CAT1 transgene mitigated oxidative damage from water stress [59]. Excessive expression of the coli trehalose synthesis A (otsA) and coli trehalose synthesis B (otsB) transgene rice, accumulation of trehalose increased and oxidative damage caused by photooxidation decreased [60]. Jang et al. [61] revealed that the bifunctional fusion of the TPS and TPP (TPSP) transgene enhanced resistance to drought, salty and cold. By activating gene GH3.13 of rice and adapting the content of IAA in leaf, stem and tuber, adaptability to the drought was enhanced [62].

\subsection{Regulator Gene with Drought Resistance}

Hou et al. [63] separated a gene named osSKIPa. Studies implied that the gene osSKIPa, an upstream gene for regulating, would mobilize the other gene of drought resistance, promote the cell vitality, increased viability in water stress. The mechanism similar to chain reaction was never founded before. Huang et al. [64] acquired the rice mutant named drought and salt tolerance (DST) through screening from mutant library large-scaly. Further; they cloned the gene DST with stress-resistance. They argued that DST down-regulated expression of the gene related to metabolization of $\mathrm{H}_{2} \mathrm{O}_{2}$, and the ability with eliminating $\mathrm{H}_{2} \mathrm{O}_{2}$ declined. This resulted in accumulation of $\mathrm{H}_{2} \mathrm{O}_{2}$, and shut of stoma in guard cells, and then improved the ability of drought-resistance by decreasing evaporation of water.

\subsection{Epigenetics Mechanism}

Epigenetics refers to the heritable changes in gene expression without any alteration in DNA sequence, including DNA methylation, histone modification and chromatin conformation $[65,66]$. DNA methylation is one of the important modifications in eukaryotic genome. It regulates genetic information from the epigenetic level including regulation of gene expression, growth and development, genomic imprinting and so on. In the recent years, researches have showed that DNA methylation would be effected in stress such as heat, drought, etc. [67], and the genes with DNA methylation were connected with stress [68]. That is to say that DNA methylation involved the expression and regulation progress of gene in stress. Pan et al. [69] argued that the level of DNA methylation increased significantly in water stress, the level and state of DNA methylation under drought was temporal-spatial specific and variety specific, and the change of DNA methylation was related to drought responsiveness.

\section{CONCLUSION}

It is important issue of water resource shortage which is harm to agriculture development of the world. Efficient use of water resources is an urgent problem around the world [70]. However, drought-resistance is a complicated problem and is regulated by several pathways involved with many genes [71]. Thus, there are several problems to resolve in the signal perceiving, the relations between several factors in signal transduction, epigenetics mechanism, transgene silence etc. Therefore, these researches would help us understand molecular mechanism in drought-resistance in depth. In addition, we should further study by integrating molecular level, cell, organ, and the whole etc. The studies would improve resistance of crops and water utilization efficiency, and establish basement for cultivating the varieties of resistance.

\section{ACKNOWLEDGEMENTS}

The authors acknowledge financial support from National Natural Science Foundation of China (30870205) and Shenyang Normal University Experimental center director foundation (SY201104).

\section{REFERENCES}

[1] Fageria, N.K. (2003) Plant tissue test for determination of optimum concentration and uptake of nitrogen at different growth stages in low land rice. Communications in Soil Science and Plant Analysis, 34, 259-270. doi:10.1081/CSS-120017430

[2] Fageria, N.K. (2007) Yield physiology of rice. Plant Nutrition, 30, 843-879.

[3] Belder, P., Spiertz, J.H.J., Bouman, B.A.M., Lu, G. and Tuong, T.P. (2005) Nitrogen economy and water productivity of lowland rice under water-saving irrigation. Field Crops Research, 93, 169-185. doi:10.1016/j.fcr.2004.09.022

[4] Jing, R.L. (2007) Advances of research on drought resistance and water use efficiency in crop plants. Review of China Agricultural Science and Technology, 9, 1-5.

[5] Bais, H.P., Vepachedu, R. and Gilroy, S. (2003) Allelopathy and etotic plant invasion: From molecules and genes to species interaction. Science, 301, 1377-1380. doi:10.1126/science.1083245

[6] Rania, B.S. and Nabil, Z. (2010) Improved drought and salt stress tolerance in transgenic tobacco overexpressing a novel A20/AN1 zinc-finger "AlSAP” gene isolated from the halophyte grass Aeluropus littoralis. Plant Molecular Biology, 72, 171-190. doi:10.1007/s11103-009-9560-4

[7] Cai, K.Z., Wu, X.Z. and Luo, S.M. (2008) Effects of water stress on osmolytes at different growth stages in rice leaves and roots. Journal of Plant Ecology, 32, 491500.

[8] Cabuslay, G.S., Ito, O. and Alejar, A.A. (2002) Physiological evaluation of responses of rice (Oryza sativa L.) to water deficit. Plant Science, 163, 815-827. doi:10.1016/S0168-9452(02)00217-0

[9] Li, D.Q., Zou, Q. and Cheng, B.S. (1992) Osmotic adjustment and osmotica of wheat cu|tivars with different 
drought resistance under soil drought. Acta Phytophysiologica Sinica, 18, 37-44.

[10] Bianchi, G., Limiroli, R. and Pozzi, N. (1993) The unusual sugar composition in leaves of the resurrection plant Myrothamnus flabellifolia. Physiologia Plantarum, 87, 223-226. doi:10.1111/j.1399-3054.1993.tb00146.x

[11] Crowe, J.H. and Crowe, L.M. (1984) Preservation of membrances in anhydrobiotic organisms: The role of thehhslose. Science, 223, 701-703. doi:10.1126/science.223.4637.701

[12] Zonglie, H., Karuna, L., Zhang, Z.M. and Desh, P.S. (2000) Removal of Feedback inhibition of delta 1-pyrroline-5-carboxylate synthetase results in increased proline accumulation and protection of plants from osmotic stress. Plant Physiology, 122, 1129-1136. doi:10.1104/pp.122.4.1129

[13] Kemple, A.R. and Macpherson, H.T. (1954) Liberation of amino acid in perennial rye grass during wilting. Biochemistry, 58, 46-49.

[14] Zaifnejad, M., Clark, R.B. and Sullivan, C.Y. (1997) Aluminum and water stress effects on growth and proline of Sorghum. Journal of Plant Physiology, 153, 338-344. doi:10.1016/S0176-1617(97)80130-7

[15] Carceller, M., Prystupa, P. and Lemcoff, J.H. (1999) Remobilization of proline and other nitrogen compounds from senescing leaves of maize under water stress. Journal of Agronomy and Crop Science, 183, 61-66. doi:10.1046/j.1439-037x.1999.00324.x

[16] Alkaraki, G.N., Clark, R.B. and Sullivan, C.Y. (1996) Phosphorus nutrition and water stress effects on proline accumulation in sorghum and bean. Journal of Plant Physiology, 148, 745-751.

doi:10.1016/S0176-1617(96)80378-6

[17] Delauney, A.J., Hu, C.A.A. and Kavi Kishor, P.B. (1993) "Cloning of ornithine delta-aminotransferase CDNA from vigna-aconitifolia by transcomplementation in Escherichia coli and regulation of proline biosynthesis. Journal of Biological Chemistry, 268, 18673-18678.

[18] Sheela, K.R and Alexallder, V.T. (1995) Physiological response of riee varieties as influenced by soil moisture and seed hardening India. Plant Physiology, 38, 269-271.

[19] Wu, L.Q., Fan, Z.M. and Guo, L. (2005) Over-expression of the bacterial nhaa gene in rice enhances salt and drought tolerance. Plant Science, 168, 297-302. doi:10.1016/j.plantsci.2004.05.033

[20] Storey, R., Ahmad, N. and Wyn Jones, R.G. (1977) “Taxonomic and ecological aspects of the distribution of glycine-betaine and related compounds in plants. Oecologia (Berl), 27, 319-332. doi:10.1007/BF00345565

[21] Foyer, C.H. and Noctor, G. (2000) Oxygen processing in photosynthesis: Regulation and signaling. New Phytologist, 146, 359-388.

[22] Porcel, R., Barea, J.M. and Ruiz-Lozano, J.M. (2003) Antioxidant activities in mycorrhizal soybean plants under drought stress and their possible relationship to the process of nodule senescence. New Phytologist, 135-143. doi:10.1046/j.1469-8137.2003.00658.x

[23] Foyer, C.H., Descourvieres, P. and Kunert, K.J. (1994)
Protection against oxygen radicals: An important defence mechanism studied in transgenic plants. 17, Plant Cell and Environment, 507-523. doi:10.1111/j.1365-3040.1994.tb00146.x

[24] Smirnoff, N. (1998) Plant resistance to environmental stress. Current Opinion in Biotechnology, 9, 214-219. doi:10.1016/S0958-1669(98)80118-3

[25] Reddya, A.R., Chaitanyaa, K.V. and Vivekanandanb, M. (2004) Drought-induced responses of photosynthesis and antioxidant metabolism in higher plants. Journal of Plant Physiology, 161, 1189-1202. doi:10.1016/j.jplph.2004.01.013

[26] Prasad, T.K. (1993) Role of active oxygen in the response of plants to water deficit and dessication. New Phytologist, 125, 27-58. doi:10.1111/j.1469-8137.1993.tb03863.x

[27] Shao, H.B., Liang, Z.S., Shao, M.A. and Wang, B.C. (2005) Changes of antioxidative enzymes and membrane peroxidation for soil water deficits among 10 wheat genotypes at seedling stage. Colloids and Surfaces B: Bio- interfaces, 42, 19-25.

[28] Seel, W.E. and Hendry, G.A. (1992) Effect of desiccations on some activated oxygen processing enzymes and anti-oxidants in mosses. Journal of Experimental Botany, 43, 1031-1037.

[29] Scandaliol, J.G. (1993) Oxygen stress and super oxide dimutases. Plant Physiology, 101, 7-12.

[30] Sun, Y.Y., Sun, Y.J., Wang, M.T., Li, X.Y., Guo, X., Hu, R. and Ma, J. (2010) Effects of seed priming on germination and seedling growth of rice under water stress. Acta Agronomica Sinica, 36, 1931-1940. doi:10.1016/S1875-2780(09)60085-7

[31] Wu, X.Z., Cai, Z.K. and Luo, S.M. (2008) Effects of soil drying at heading stage on physiological characteristics in root and leaf of rice. Chinese Agricultural Science Bulletin, 24, 202-207.

[32] Yin, Y.Q., Hu, J.B. and Deng, M.J. (2007) Latest development of antioxidant system and responses to stress in plant leaves. Chinese Agricultural Science Bulletin, 23, 105-110.

[33] Shao, H.B., Chu, L.Y., Shao, M.A., Jaleel, C.A. and Mi, H.M. (2008) Higher plant antioxidants and redox signaling under environmental stresses. Comptes Rendus Biologies, 331, 433-441. doi:10.1016/j.crvi.2008.03.011

[34] Santner, A., Calderon-Villalobos, L.I.A. and Estelle, M. (2009) Plant hormones are versatile chemical regulators of plant growth. Nature Chemical Biology, 5, 301-307. doi:10.1038/nchembio.165

[35] Wolters, H. and Gurgens, J. (2009) Survival of the flexible: Hormonal growth control and adaptation in plant development. Nature Reviews Genetics, 10, 305-317. doi:10.1038/nrg2558

[36] Yin, Z.M., Hennig, J. and Szwacka, M. (2004) Tobacco $\mathrm{PR}-2 \mathrm{D}$ promoter is induced in transgenic cucumber in response to biotic and abiotic stimuli. Journal of Plant Physiology, 161, 621-629. doi:10.1078/0176-1617-00737

[37] Hieng, B., Ugrinovic, K. and Sustar-Vozlic, J. (2004) Different classes of proteases are involved in the response to drought of Phaseolus vulgaris L. cultivars differing in 
sensitivity. Journal of Plant Physiology, 161, 519-530. doi:10.1078/0176-1617-00956

[38] Wu, G.H., Robertson, A. and Liu, X.J. (2004) A lipid transfer protein gene BG-14 is differentially regulated by abiotic stress, ABA, anisomycin, and sphingosine in bromegrass (Bromus inermis). Journal of Plant Physiology, 161, 449-458. doi:10.1078/0176-1617-01259

[39] Serna, L. (2005) A network of interacting factors triggering different cell fates. Plant Cell, 16, 2258-2263. doi:10.1105/tpc.104.160931

[40] Larkindale, J. and Huang, B.R. (2004) Thermotolerance and antioxidant systems in Agrostis stolonifera: Involvement of salicylic acid, abscisic acid, calcium, hydrogen peroxide, and ethylene. Journal of Plant Physiology, 161, 405-413. doi:10.1078/0176-1617-01239

[41] Davies, W.J. and Zhang, J. (1991) Root signals and the regulation of growth and development of plants in drying soil. Annual Review of Plant Physiology and Plant Molecular Biology, 42, 55-76. doi:10.1146/annurev.pp.42.060191.000415

[42] Wrigh, S.T.C. and Hiron, R.W.P (1969) (+)-Abscisic acid, the growth inhibitor induced in detached wheat leaves by a period of wilting. Natrue, 224, 719-720. doi:10.1038/224719a0

[43] Jackson, M.B. (1993) A replant homones in volved in the root to shoot communication. Advances in Botanical Research, 85, 183-187.

[44] Chen, X.H., Liu, K., Xi, L.L., Wang, Z.Q. and Yang, J.C. (2005) Effects of soil moisture and nitrogen on abscisic acid and cytokinin contents in the above ground plant parts of rice. Acta Agronomica Sinica, 31, 1406-1414.

[45] Chen, Y.M. and Yu, S.W. (1988) Effects of ethylene release and content of ACC and MACC in drought stressses of different modes to wheat. Plant Physiology Journal, 14, 281-288.

[46] Chen, J., Wan, J., Gao, X.L., Jiang, H. and Wang, P.R. (2006) Study on drought resistance physiology and drought resistance genes of rice. Chinese Agricultural Science Bulletin, 22, 56-60.

[47] Yang, J.C., Liu, K., Zhang, S.F., Wang, X.M., Wang, Z.Q. and Liu, L.J. (2008) Hormones in rice spikelets in responses to water stress during meiosis. Acta Agronomica Sinica, 34, 111-118. doi:10.1016/S1875-2780(08)60005-X

[48] Singh, J., Nakamum S. and Ota, Y. (1993) Effect of epi-brassi-nolide on gram (Cicer arietinum) plant grown under water stress in juvenilstage. Indian Journal of a cultural Science, 1993, 63, 395-401

[49] Kairam, S.R. (1994) Effect of homobrassinilide application on plant metalolism and grain yield under irrigated and moisture stress conditions of two wheat varieties. Plant Growth Regulation, 14, 173-179. doi:10.1007/BF00025220

[50] Moons, A., Prinsen, E. and Bauw, G. (1997) Antagonistic effects of abscisic acid and jasmonates on salt stress-inducible transcripts in rice roots. The Plant Cell, 9, 22432259.

[51] Gao, X.P., Wang, X.F. and Lu, Y.F. (2004) Jasmonic acid is involved in the water-stress-induced betaine accumulation in pear leaves. Plant Cell and Environment, 27, 497507. doi:10.1111/j.1365-3040.2004.01167.x

[52] Gonzaliez, A., Tiznado, H.M. and Zavaleta, G.R. (2004) Methyl jasmonate treatments reduce chilling injury and activate the defense response of guava fruits. Biochemical and Biophysical Research Communications, 313, 694701. doi:10.1016/j.bbrc.2003.11.165

[53] Thaler, J.S., Owen, B. and Higgns, V.J. (2004) The role of the jasmonate response in plant susceptibility to diverse pathogens with a range of lifestyles. Plant Physiology, 135, 530-538.

[54] Creelm, R.A. and Mulent, J.E. (1995) Jasmonic acid distribution and action in plants: Regulation during development and response to biotic and abiotic stress. Proceedings of the National Academy of Sciences of the USA, 92, 4114-4119.

[55] Muhammad, F., Abdul, W. and Lee, D.J. (2009) Exogenously applied polyamines increase drought tolerance of rice by improving leaf water status, photosynthesis and membrane properties. Acta Physiologiae Plantarum, 31, 937-945. doi:10.1007/s11738-009-0307-2

[56] Wu, G., Wang, X.L., Li, X.B., Kamiya, Y., Otegui, M.S. and Joanne, C. (2011) Methylation of a phosphatase specifies dephosphorylation and degradation of activated brassinosteroid receptors. Science, 4, 29.

[57] Shinozaki, K. and Yamaguchi-Shinozaki K. (2000) Molecular responses to dehydration and low temperature: Differences and cross-talk between two stress signaling pathways. Current Opinion in Plant Biology, 3, 217-223.

[58] Holmberg, N. (1998) Improving stress tolerance in plants by gene transfer. Trends in Plant Science, 3, 1361-1366. doi:10.1016/S1360-1385(97)01163-1

[59] Zhao, F.Y. and Xu, Z.J. (2009) Physiological changes of transgenic rice under drought and heat stress. Acta Botanica Boreali-Occidentalia Sinica, 29, 240-248.

[60] Garg, A.K., Kim, J.K. and Owens, T.G. (2002) Trehalose accumulation in riceplants confershightolerance levelsto different abiotic stresses. Proceedings of National Academy of Science of USA, 99, 15898-15903. doi:10.1073/pnas.252637799

[61] Jang, I.C., Oh, S.J. and Seo, J.S. (2003) Expression of a bifunctional fusion of the Escherichia coli genes for trehalose-6-phosphate synthase and trehalose-6-phosphate phosphatase in transgenic rice plants increases trehalose accumulation and abiotic stress tolerance without stunting growth. Plant Physiology, 131, 516-524. doi:10.1104/pp.007237

[62] Zhang, S.-W., Li, C.-H., Cao. J., et al. (2009) Altered architecture and enhanced drought tolerance in rice via the down-regulation of indole-3-acetic acid by TLD1/ OsGH3.13 activation. Plant Physiology, 151, 1889-1901. doi:10.1104/pp.109.146803

[63] Hou, X., Xie, K.B., Yao, J.L., Qi, Z.Y. and Xiong, L.Z. (2009) A homolog of human ski-interacting protein in rice positively regulates cell viability and stress tolerance. Proceedings of National Academy of Science of USA, 106, 6410-6415.

[64] Huang, X.Y., Chao, D.Y., Gao, J.P., Zhu, M.Z., Shi, M. 
and Lin, H.X. (2009) A previously unknown zinc finger protein, DST, regulates drought and salt tolerance in rice via stomatal aperture control. Genes \& Development, 23, 1805-1817.

[65] Wu, C.T. and Morris, J.R. (2001) Genes, genetics and epigenetics: A correspondence. Science, 293, 1103-1105. doi:10.1126/science.293.5532.1103

[66] Bird, A.P. (1986) CpG-rich islands and the function of DNA methylation. Nature, 321, 209-212. doi:10.1038/321209a0

[67] Finnegan, E.J., Bretell, R.I. and Dennis, E.S. (1993) The role of DNA methylation in the regulation of plant gene expression. In: Jost, J.P. and Saluz, H.P., Eds., DNA Methylation: Molecular Biology and Biological Significance, Birkhauser Verlag, Basel, 218-261.
[68] Wada, Y., Miyamoto, K., Kusano, T. and Sano, H. (2004) Association between up-regulation of stress-responsive genes and hypomethylation ofgenomic DNA intobaccoplants. Molecular Genetics and Genomics, 271, 658666. doi:10.1007/s00438-004-1018-4

[69] Pan, Y.J., Fu, B.Y., Wang, D., Zhu, L.H. and Li, Z.K. (2009) Spatial and temporal profiling of DNA methylation induced by drought stress in rice. Scientia Agricultura Sinica, 42, 3009-3018.

[70] Luo, L.J. (2010) Breeding for water-saving and droughtresistance rice (WDR) in China. Journal of Experimental Botany, 61, 3509-3517. doi:10.1093/jxb/erq185

[71] Elizabet, P. (2008) The blue revolution, drop by drop, gene by gene. Science, 320, 171-173. 